IZA DP No. 9866

The Value of Social Security: Are Formal Jobs Better?

Lucia Madrigal

Carmen Pagés

Agustina Suaya

April 2016 


\title{
The Value of Social Security: Are Formal Jobs Better?
}

\author{
Lucia Madrigal \\ InterAmerican Development Bank \\ Carmen Pagés \\ InterAmerican Development Bank \\ and IZA \\ Agustina Suaya \\ InterAmerican Development Bank
}

Discussion Paper No. 9866

April 2016

IZA

P.O. Box 7240

53072 Bonn

Germany

Phone: +49-228-3894-0

Fax: +49-228-3894-180

E-mail: iza@iza.org

Any opinions expressed here are those of the author(s) and not those of IZA. Research published in this series may include views on policy, but the institute itself takes no institutional policy positions. The IZA research network is committed to the IZA Guiding Principles of Research Integrity.

The Institute for the Study of Labor (IZA) in Bonn is a local and virtual international research center and a place of communication between science, politics and business. IZA is an independent nonprofit organization supported by Deutsche Post Foundation. The center is associated with the University of Bonn and offers a stimulating research environment through its international network, workshops and conferences, data service, project support, research visits and doctoral program. IZA engages in (i) original and internationally competitive research in all fields of labor economics, (ii) development of policy concepts, and (iii) dissemination of research results and concepts to the interested public.

IZA Discussion Papers often represent preliminary work and are circulated to encourage discussion. Citation of such a paper should account for its provisional character. A revised version may be available directly from the author. 
IZA Discussion Paper No. 9866

April 2016

\section{ABSTRACT}

\section{The Value of Social Security: Are Formal Jobs Better?*}

As the population ages, low and unequal social security coverage are among the most pressing challenges in the Latin American region. On average, only $45 \%$ of workers contribute to social security, and this figure is much lower for low-income and low-skilled individuals. There are many hypotheses for this limited and uneven coverage. This paper studies two of them: First, we test whether individuals do not contribute to social insurance because, due to myopia or limited information, they place little value in social insurance. Second, we test whether low-income, low-skilled individuals have a lower value of social insurance than higher-income or higher-skilled individuals. Using an indirect method to estimate individual social security valuation based on self-reported job satisfaction, we find that workers attain higher job satisfaction in formal than in informal jobs in Peru but not in the case of Mexico. In addition, we find little evidence that the value of social insurance increases with income or education. If anything, the opposite is the case, with lower-income or lowereducation individuals deriving higher utility from having access to social insurance.

JEL Classification: J21, J28, O17

Keywords: $\quad$ job satisfaction, informality, social insurance, Latin America

Corresponding author:

Carmen Pagés

InterAmerican Development Bank

1300 New York Avenue, NW

Washington DC 20577

USA

E-mail: carmenpag@iadb.org

\footnotetext{
* The authors are grateful to seminar participants at IZA/World Bank Conference June 2014 and LACEA Conference in October 2015 for their comments and suggestions. All errors remain our own responsibility. This paper represents the opinions of the authors and not those of the Inter-American Development Bank or its board of directors.
} 


\section{Introduction}

Despite moderately high growth during the last decade and the expansion of social policies in Latin America, social security coverage remains stubbornly low and unequal. Measured by active coverage, that is, the percentage who contribute to social security through their jobs, only $44.7 \%$ of workers contribute to social security, and these figures are even lower for low-income or loweducation workers (Bosch, Melguizo, and Pagés 2013). While 73\% of workers in the highest individual income quintile in Latin America contribute to social insurance, only $21 \%$ of the lowest income quintiles do so, and the percentage of those who contribute is monotonically increasing in individual income (graph 1).

Likewise, contribution rates increase monotonically with education levels. While $70 \%$ of workers with higher education are contributing to social insurance, only $49 \%$ of those with secondary education completed and $28 \%$ of those with less than secondary completed do so (graph 2). Explaining these patterns, which hold true in every country of the region, remains an open issue. Given this situation, many countries have attempted to increase social insurance coverage by implementing noncontributory pensions and health insurance, through programs financed by general revenues rather than by the contributions of workers and firms (Roffman 2014). However, the benefits tend to be low (particularly in pensions) and often targeted to the poorest workers. Therefore, they only attenuate but do not solve the problem of inadequate coverage for the majority of the population. ${ }^{1}$

In this context, it becomes crucial to understand the reasons behind the low and unequal rates of contribution into social security. This paper studies two related hypotheses: First, we test whether individuals do not contribute because, due to myopia or limited information, they place little value in social insurance. Second, we test whether low-income or low-skilled individuals have a lower valuation of social insurance than higher-income or higher-skilled individuals.

For a formal match to occur, a firm must be willing to hire, and a worker must be willing to accept the offer. That is, for the firm, the value of the marginal product of the worker must be higher than the wage plus non-wage costs, and for the worker, the value of the job offer (in terms of wages and benefits) must be better than alternative job opportunities in the informal sector. If the

\footnotetext{
${ }^{1}$ Another matter is whether instituting noncontributory programs reduces the incentives of workers and firms to pay into social security, therefore creating unpleasant trade-offs between contributory and noncontributory coverage. See for example, Levy (2008) and Bosch, Melguizo, and Pagés (2013).
} 
valuation of the benefits offered by social security is low, workers may rather work in informal jobs where they can skip paying into social security and, increasingly, they can get benefits free of cost. If, due to myopia, limited information, or access to programs offered to informal sector workers free of costs, the valuation of social security is lower for lower-income, lower-skilled individuals, this could explain why participation into social security is so low at the low end of the distribution.

This paper is related to a strand of literature that seeks to explain the causes of informal employment in emerging and developing economies. The contribution status to social security is a common measure of formality of employment, and therefore, the existence of informal employment and the low coverage of social security go hand in hand. The economic literature has long debated whether the informal sector is a result of exclusion or choice. Under the first view, informal workers value formal jobs, but there are not enough job opportunities made available to them. In contrast, the second view states that workers value the autonomy, independence, or flexibility regarding work schedules associated with informal sector jobs (Maloney 2004; Perry et al. 2007). Some individuals may also value not paying taxes and social security contributions from which they derive little value (Maloney 2004). This may be particularly relevant if governments provide free-of-charge social services targeted to informal workers (Levy 2008). Put differently, workers choose to be in the informal sector if, when comparing the wages and amenities in the formal and informal sectors as well as the mandatory contributions to access those benefits in the formal sector, a worker's utility is higher in the informal sector.

In order to identify whether the hypothesis of exclusion or that of choice better explains the existence of the informal sector, studies have resorted to different methodologies. One is to study workers' mobility patterns. If workers prefer formal employment, they will voluntarily move from informal to formal sector jobs, while involuntary mobility will go in the opposite direction. Studies of mobility find high rates of mobility across formal and informal salaried jobs and low mobility between formal salaried jobs and self-employment (Maloney 1999; IDB 2004; Bosch and Maloney 2007; Pagés and Stampini 2007; Green 2010). They also find that mobility is higher from informal salaried to formal salaried jobs, consistent with a higher preference for formal salaried jobs. Mobility studies, however, do not fully solve the problem because, to date, existing data do not permit observing whether mobility is voluntary or involuntary.

In this paper, we employ a different approach. To assess whether individuals are better off in jobs that offer social insurance and whether the valuation of social insurance differs among workers across income/skills groups, we assess how social insurance affects job satisfaction in two countries: Mexico and Peru. To the extent that social security is a valuable job amenity, we can 
infer its value by assessing how much a worker values his/her job when the job provides social security benefits. Therefore, the fact that job satisfaction increases with social security contributions gives information on the valuation of social protection and formal jobs.

To our knowledge, this is the first study that uses this methodology to measure valuation of social insurance, although this approach has been used extensively in the literature to assess the valuation of performance pay (Cornelissen, Heywood, and Jirjahn 2011), relative pay (Card et al. 2012), or part-time work (López Bóo, Madrigal, Pagés 2010), among others. This methodology is particularly valuable because self-reported valuation is usually unreliable (Jaramillo 2013).

To study these hypotheses, we used data from two household surveys conducted in Mexico City, Mexico, and Lima, Peru, in 2008. These data are special in that, in addition to the standard questions found in regular household surveys, they include a large number of questions related to attitudes toward social insurance and the nature of the job held by a person, including job satisfaction and perceived job stability. These allowed us to control for differences in a large number of personal and job characteristics, which is useful to disentangle the effect of social insurance from the effect of a number of correlated job and personal characteristics that can influence job satisfaction.

Our results suggest important differences across countries: While in Peru, the results indicated that workers value social insurance, in Mexico, we found little effect of social insurance once other important variables such as job security were controlled for. In addition, we found that valuation does not increase with income or education levels. These results were not driven by omitted variable bias or endogeneity because, to account for that, we also estimated the effect of social insurance on job satisfaction by means of instrumental variable estimation. Once the potential endogeneity was taken into account, we found an ever stronger impact of social insurance on job satisfaction for Peru and no effect of social insurance on job satisfaction in Mexico. The results also corroborated that the valuation of social insurance does not increase with income or education. If anything, according to the Instrumental Variables (IV) estimates, the valuation of social security tends to decrease with income (in Peru) or education (in Mexico), suggesting that lower-income individuals benefit more from having access to social insurance than the higher-income/skills population.

The rest of this paper is organized as follows: section 2 presents the empirical approach used in this study; section 3 describes the data for Mexico and Peru used in this paper and a summary of the relevant descriptive statistics; section 4 discusses the estimation results; section 5 presents the results correcting for endogeneity, and finally, section 6 concludes. 


\section{Estimation Methodology}

In this paper, we assume that the utility function of working in a formal job is given by the individual's wage (net of social insurance contributions) plus a nonpecuniary benefit package that is associated with a formal job. Similarly, the utility function of informal workers (individuals not contributing to social security) is the sum of a wage and a set of benefits associated with informal jobs. Therefore,

$$
\begin{aligned}
U_{(\text {formal })} & =\text { wage }_{(\text {formal })}+\text { benefits }_{(\text {formal })}, \\
U_{(\text {informal })} & =\text { wage }_{(\text {informal })}+\text { benefits }_{(\text {informal })} .
\end{aligned}
$$

If workers are free to choose the job that better suits them, they will take on an informal job if the value of this job is higher than the value of a formal job offer. That is,

$$
U_{(\text {informal })}-U_{(\text {formal })}>0,
$$

which may arise if differences in net wages, as well as aspects such as flexibility in working hours, or not paying taxes increase the value of $U_{(\text {informal })}$. This simple theoretical framework has been used in other papers, such as the one developed by Azuara and Marinescu (2013), and suggests that the decision of not contributing may be driven by preferences regarding job amenities and costs. To

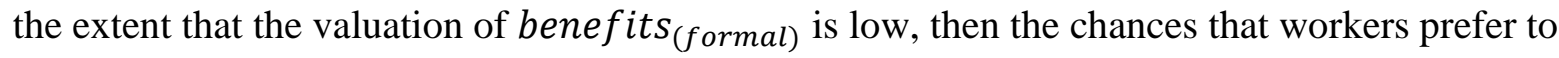
work in informal jobs increases. In addition, to the extent that this valuation increases with income, it can explain why higher-income/higher-skilled individuals work in the formal sector.

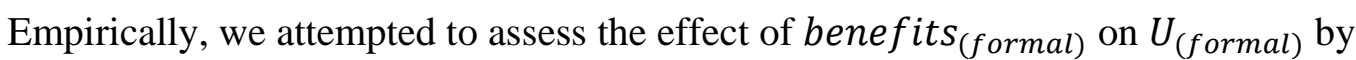
estimating the determinants of self-reported job satisfaction $\left(J S_{i}\right)$ as a function of (1) the social security status, $X_{i}$, which identifies contribution to the pension system (our definition of formality); (2) a vector $Z_{1 i}$ of observable basic personal characteristics (gender, salaried, age, marital status, education, health status); (3) a vector $Z_{2 i}$ of additional personal characteristics normally not available in regular household surveys, such as whether the person has thought of how to finance old age, smoking habits, planning habits, discount rates, risk aversion, time spent budgeting, and access to six months of income in case of an emergency; and (4) a vector $Z_{3 i}$ of job characteristics such as hours of work, industry, firm size, perceived job security, and earnings. Lastly, $\varepsilon_{i}$ denotes an error term. Therefore, we estimated the following model:

$$
J S_{i}=U\left(X_{i}, Z_{1 i}, Z_{2 i}, Z_{3 i}, \varepsilon_{i}\right)=\alpha+X_{i} B_{0}+Z_{1 i} B_{1}+Z_{2 i} B_{2}+Z_{3 i} B_{3}+\varepsilon,
$$

where $B_{1}, B_{2}$, and $B_{3}$ are vectors of coefficients. As the dependent is a categorical ordered variable, we estimated this model by means of an ordered probit approach in order to use all the variability in responses. We reported marginal effects for the "very satisfied" option. In addition, to assess the 
robustness of our results, we used a linear probability (OLS) model with a dummy dependent variable of job satisfaction.

As stated, this paper tests two different hypotheses. First we assess whether people value access to social insurance by assessing whether job satisfaction increases for individuals who get access to pensions or health insurance through their jobs. Second, we test whether higher-income or higher-skilled individuals experience higher valuation of social insurance access. If this is the case, this could explain why these types of workers tend to experience higher rates of affiliation to social insurance than lower-income/less skilled individuals. The second hypothesis is relevant in the sense that it could be the case that only people with a higher level of education or income value the social protection. If this is the case, an important avenue for policy would be to implement programs to foster higher valuation of benefits among groups at the low end of the distribution. In order to examine whether there are differences among social groups, we estimated the ordered probit models separately for each group in addition to lumping all income/education groups and adding an interaction term between income or education and contribution status.

\section{Identification Issues}

There are at least two potential problems with relying on the OLS model presented in the last section. First, job satisfaction may be measured with error, and a possible correlation between the dependent variable and the error term may exist. Such correlation could emerge when dealing with individual perception-based variables in the estimation. It is possible that the answers given are influenced by an individual's ability or sociability. For example, sociable workers will be more satisfied with their jobs than less sociable workers. Second, contribution to social security is not an exogenous characteristic; in fact, status of contribution can be jointly determined by job satisfaction. This means that there are other unobservable characteristics included in the error term $\varepsilon_{\mathrm{i}}$ that affect both job satisfaction and contribution and therefore violate the zero conditional mean assumption due to omitted variable bias.

In order to account for the endogeneity of contributions to social security, we performed Instrumental Variables estimation by means of a two-stage least squares (2SLS) estimate. Related papers in the literature that measure the effect of financial literacy on stock market participation, have also resorted to Instrumental Variables estimation using 2SLS or Generalized Method of Moments (GMM) to control for the endogeneity of their variables of interest (van Rooij, Lusardi, and Alessie 2011; Lusardi and Mitchell 2014). 
In this study, we used two different instruments; the first is the number of friends of the respondent who contribute to the pension system. The survey contained a question that asked individuals: "Think of five of your closest friends (no relatives): How many of them currently contribute to the pension system?” This variable is likely to be correlated with the contribution status and, at the same time, not affect job satisfaction directly. That is, the peer effect is not likely to affect a worker's job satisfaction other than through the endogenous variable. However, it is important to note that this exclusion restriction might be violated if those friends are coworkers. Unfortunately, we cannot observe in the database the workplace of the respondents' friends.

To assess robustness, we also used a second instrument in the estimation. It measured the degree of comprehension regarding the information presented in a pension statement. The hypothesis is that an individual who is more familiar with the type of information presented in a pension statement will be more likely to contribute, while at the same time, this variable is not directly related to job satisfaction. In the questionnaire, the interviewees received a pension statement and were asked to identify some information in it, such as account balance, period of coverage, and total commission charged. Following those questions, they were asked, "Would you say that this pension statement is . . . ?” and the potential answers were "easy to understand/not so easy to understand/difficult to understand/very difficult to understand/I can't read.” This instrument may not be free of problems itself, due to its potential correlation with an individual's ability and, through it, with job satisfaction. Our reasoning, however, was that if both instruments yielded similar results, despite being very different in nature-one is potentially correlated with job satisfaction through a respondent's coworkers, the other through the respondent's ability-it would give us higher confidence in the validity of our results.

We estimated the model by instrumental variables by means of a 2SLS model with the first step estimation given by the following equation:

$$
X_{i}=\xi_{1 i} B_{0}+Z_{1 i} B_{1}+Z_{2 i} B_{2}+Z_{3 i} B_{3}+\varepsilon_{i}
$$

and the second step given by equation (4) and where $X_{\mathrm{i}}$ is a dichotomous variable that takes the value of 1 if the individual contributes to social security in his or her job and 0 otherwise, $\xi_{1 \mathrm{i}}$ is the instrument, and, as in model (4), $Z_{1 i}$ is a vector of individual characteristics, $Z_{2 i}$ is a vector of additional personal characteristics, and $Z_{3 i}$ is a set of job characteristics. The first instrument given by "number of friends who contribute to social insurance" is a continuous variable that takes a value 
from 0 to 5. The second, the individual's familiarity with a pension statement, is also a continuous variable that takes a value from 1 to 4 representing the scale "very difficult to understand" to "very easy.” We also used both instruments together in the same estimation in order to test for overidentification.

\section{Data and Descriptive Statistics}

The analysis in this paper uses information from two household surveys conducted in Mexico City, Mexico, and Lima, Peru, in 2008. The Inter-American Development Bank conducted the surveys with the help of two specialized local surveying firms. The surveys are representative at the urban level and gather data from individuals, 25 to 55 years old, who were employed at the time of the survey. Additionally, a qualified respondent answered information about the household. The data contain information on 3,700 individuals in Mexico and about 6,800 individuals in Peru.

For each country, the survey asked people about their individual and job characteristics, living conditions, education attainment, and health status, among many others. Importantly, it also contained information on job satisfaction, which was measured with the question "Are you satisfied with the work you do?” In Mexico, the possible answers were given by a scale from 1 to 4 . In the scale, 1 meant "very unsatisfied,” 2 “unsatisfied,” 3 “satisfied,” and 4 “very satisfied.” In Peru, there were five categories: 1 "very unsatisfied,” 2 “unsatisfied,” 3 “indifferent,” 4 "satisfied,” and 5 "very satisfied."2 Scale indicators of job satisfaction are more reliable than dummy variables (are you satisfied? yes/or no), as explained by Gao and Smith (2010). Therefore, in this paper, job satisfaction is measured as a scale, although in order to develop some robustness checks and control for possible endogeneity problems discussed later, in some models, we specify it as a dummy variable that takes the value of 1 if the person reported that he or she was satisfied or very satisfied with the work he or she does and 0 otherwise. As we will show, the transformation of the dependent variable does not change the results significantly.

Our variable of interest was an indicator variable that took a value of 1 if the person contributed to a pension in the last three months and 0 otherwise. We refer to this as the pensionbased definition. In addition, we have used an alternative definition based on access to a health care

\footnotetext{
2 The results are robust to different codifications of job satisfaction, such as eliminating the category “indifferent” in Peru and using the same codification as in Mexico or as shown in the paper, defining a binary variable where categories 1-2 are defined as "not satisfied” and categories 3-4 or 3-5 are defined as "satisfied.”
} 
system constructed with a different variable as a robustness check. ${ }^{3}$ While in principle all workers enrolled in social insurance contribute to both health and pensions simultaneously, in practice, some workers contribute to one but not the other. Nonetheless, the results are very similar with both variables. We labeled as informal workers those who were not enrolled in pension or health insurance.

Before describing the individual level data, we contextualize the countries under study. Table 1 presents some basic information about Mexico and Peru in terms of regulations and policies in the area of social security. Differences in system characteristics can affect valuation of benefits and therefore explain differences in estimation results across countries. In both countries, contribution to social insurance is mandatory only for salaried workers.

To qualify for a minimum pension, workers need to contribute for longer periods in Peru, and the retirement age is also higher in Peru than in Mexico (70 and 65 years old, respectively). In consequence, gross replacement rates are considerably higher in Peru. Regarding noncontributory programs, they are somewhat more extended in Mexico than in Peru. The coverage of noncontributory health programs around the time of the survey was of the order of $32 \%$ in Mexico and $28 \%$ in Peru. Likewise, the coverage of noncontributory pensions was 63\% in Mexico and 41\% in Peru.

Minimum wages are similar in dollar terms in both countries. However, they are lower in Mexico than in Peru when assessed relative to income per capita, As a consequence, a higher percentage of people earn an income below the minimum wage in Peru than in Mexico. Finally, labor costs as a percentage of GDP per capita are substantively higher in Peru than in Mexico (40\% in Peru versus 10\% in Mexico). All in all, these figures suggest higher benefits in the contributory program in Peru (at a higher cost) and higher availability of noncontributory benefits in Mexico, which, from the worker side, may lead to a higher preference for informal jobs in Mexico. Likewise, higher labor costs in Peru may reduce formal job creation and lead to higher scarcity of formal jobs in Peru than in Mexico. These factors combined would predict a higher preference for informality in Mexico and a higher exclusion of informality in Peru.

Graph 3 shows the distribution of job satisfaction in both countries. Mexico's distribution is skewed to the right, where most of the workers report being satisfied (category 3) or very satisfied with their jobs (category 4). In the case of Peru, most workers report being satisfied with their jobs

\footnotetext{
${ }^{3}$ Results available upon request.
} 
(category 4). This information is also presented in table 2, which shows standard deviation and the number of observations of this variable in both countries.

Table 2 reports weighted summary statistics for Mexico City and metropolitan Lima for the sample of employed individuals 25-55 years old. Job satisfaction and contribution rates are higher in Mexico City, than in Lima (91\% vs. 68\% and 36\% vs. 28\%, respectively). Also, a higher percentage of workers are salaried in the Mexican sample (70\% in Mexico City vs. 55\% in Lima). The proportion of males in the workforce 25-55 is 62\% in Mexico and 59\% in Peru. The share of married workers is higher in Mexico than in Peru (50\% vs. $32 \%$ ), as is the share of workers with chronic health conditions (12\% vs. 9\%).

Regarding education, we classify the education variable in three categories: "less than secondary completed," "secondary completed," and "some tertiary or university.” The percentage of workers who have some tertiary education is higher in Mexico than in Peru (45\% vs. 38\%). The data also contain interesting information about behaviors and attitudes regarding risk and social insurance. For example, fewer workers in Mexico have thought of how to finance their pensions (34\% in Mexico vs. 42\% in Peru). Similarly, Mexican workers are less likely to plan things with a lot of detail (52\% vs. 62\% in Peru) and are more present oriented (42\% vs. 36\% in Peru). They are also less likely to spend time budgeting (55\% vs. $77 \%$ in Peru). Mexican workers are also more likely to smoke than Peruvian workers (32\% vs. $13 \%$ ). In both countries, around $25 \%-26 \%$ of the workers are risk averse. Also, in both countries, 37\% of workers report that, in case of an emergency, they could get access to the equivalent of six months of their income. The variable probability of being fired describes self-reported answers to the question "How likely is it that you will get fired from the place you work?” The answers were given as one of four options from 1 to 4 : $1=$ not probable, 2 = low probability, 3 = somehow probable, 4 = very probable. On average, this variable was between 1 and 2 in both countries, with a slightly higher value in Mexico.

Regarding job characteristics, workers in both urban areas work long hours per month, an average of 212 hours in Mexico and 222 in Peru. In terms of sector distribution, manufacturing represents only $10 \%$ of employment in Mexico and 16\% in Peru. Also, in the Mexican data, a larger percentage of workers are employed in large firms (more than 10 workers) than in Peru (45\% vs. 34\%). Also, incomes, measured in logarithms of US dollars adjusted by 2008 purchasing power parity, are higher in Mexico than in Peru.

Average job satisfaction was higher among people who reported contributing to social security than among those who did not. In Peru, 85\% of contributing individuals reported being satisfied with their jobs, compared with $64 \%$ among those who were not contributing. The same 
pattern emerges in Mexico: 94\% of contributors declared being satisfied at their jobs versus only $87 \%$ among non-contributors. These differences in means are significantly different from zero in both countries. However, they could be related to factors other than contributing to social security. We explore the relationship between contributing to social security (or formality) and job satisfaction in more detail in the rest of the sections of this paper.

\section{Estimation Results}

\section{Do Workers Value Access to Social Security?}

Table 3 reports the results of an ordered probit model for Peru for a sample of workers aged 25-55 years old. All specifications (columns 1-7) show a positive and significant coefficient for the “contribute” variable, as expected. This indicates that contributing to the social security system is associated with higher job satisfaction, and therefore, indirectly, it suggests that individuals value having access to social security. The first specification, with no controls, reports that contribution is associated with an increase of 10 percentage points in the probability of being very satisfied with the job; this coefficient is positive and significant at $1 \%$. As can be seen in the following four columns, the coefficient of contribution is robust to the addition of basic characteristics as controls in column 2, other individual characteristics in column 3, job characteristics in columns 4 and 5 , and labor income in column 6.

Given that formal sector jobs are associated with higher employment stability (Alaimo et al. 2015), it is important to control for some measure of job instability to assess whether the positive association between the "contribute” variable and job satisfaction is mediated by job security. As emphasized by previous studies (OECD 2014), job stability is strongly associated with higher job satisfaction. However, controlling for how secure a worker feels in his or her job does not alter the main conclusion, nor does it alter much the value of the "contribute" coefficient. It is also noteworthy that the association between job satisfaction and the "contribute" variable is not driven by differences in the number of hours or the industry (column 5). Likewise, controlling for labor income (column 6) does not alter the positive association between the "contribute” variable and job satisfaction. As expected, the coefficient on earnings is positive, and its magnitude suggests that a $10 \%$ increase in income is associated with a 1 percentage point increase in the probability of job satisfaction.

As shown in column 6, salaried, male, older, and present-oriented workers are less likely to report high job satisfaction. Similar results have been found in other papers (IDB 2008; Pagés and 
Madrigal 2008; Perry et al. 2007), where workers report a preference for being self-employed. At the same time, workers with high education, who have thought on how to finance their old age, and who have access to funds equivalent to six months of their income in case of an emergency are also more likely to report being very satisfied with their jobs.

Column 7 reports the results of a linear probability model, where the dependent variable takes the value of 1 if the person is satisfied or very satisfied with his or her job and 0 otherwise. The coefficient is 12 percentage points, which is similar in sign and relative magnitude to the results obtained with the ordered probit model in columns 1-5 that reports coefficients for the "very satisfied" category.

Table 4 reports the same exercise for Mexico. Column 1 shows the effect without controls. Contributing to social security increases the probability of reporting higher job satisfaction by 13 percentage points. When adding basic characteristics (in column 2), the coefficient of the variable of interest decreases by 3 percentage points, but it is still significant. The coefficient, however, ceases to be statistically significant when adding other individual characteristics and job characteristics in columns 3-5 or when adding labor income (column 6). These results indicate that the relationship between the "contribute" variable and job satisfaction is more muted in the case of Mexico than in that of Peru (table 3). This is again evident comparing the results of the linear probability model in column 7 in tables 3 and 4 . While the coefficient for Peru is 0.12 , the coefficient for Mexico is only 0.04 . This suggests that the difference in statistical significance of the coefficient cannot be attributed solely to the lower number of observations in the Mexico survey.

As in the case of Peru, in Mexico salaried workers are less likely than the self-employed to report they are very satisfied with their jobs. Likewise, more educated workers, planners, and the ones with access to six months of income are more likely to report higher job satisfaction. Similarly, labor income is positively associated with job satisfaction, while job instability is strongly negatively associated.

In summary, results for Peru suggest that workers value significantly more those jobs that provide access to social security, even when a large set of other variables that can mediate this relation are accounted for. Instead, the results for Mexico show a more muted relationship, with social security having a much smaller and not statistically significant effect on job security. In the latter part of the paper, we discuss the potential sources of these differences. 


\section{Explaining Differences across Income and Education Groups}

To assess whether the markedly lower participation in social security of low-income, lowskilled workers can be explained by differences in their valuation of social security, we split the sample according to education and income. Table 5 presents the results as distinguished by income groups (Peru in panel A, Mexico in panel B). In both panels, column 1 shows, as a reference, the results found in tables 3 and 4, column 6. In Peru, coefficients are statistically significant for secondary completed or tertiary, but not for less than secondary completed. However, the difference in significance is largely driven by the smaller number of observations. Judging by the size of the coefficients, we found that, if anything, social security valuation appears lower for those with higher education. The specification presented in column 5 tests whether there are significant differences across the coefficients by means of the "contribute" variable interacting with education groups. Yet, the results suggest that differences across the coefficients are not statistically significant.

In contrast, in Mexico (panel B) the coefficient of social security contribution is not significant for any level of education. Comparing the size of the coefficients across countries, we estimated similar coefficients for both except for the group with less than secondary completed. This suggests that the main difference across the overall coefficients presented in column 1 is due to this education group. However, as in the case of Peru, we did not find differences in social security valuation across education groups to be statistically significant in Mexico.

We repeated this exercise by splitting workers across income groups (table 6 shows the results for Peru in panel A and Mexico in panel B). These tables also include as reference in column 1 the results of tables 3 and 4, column 6 . The coefficients for the "contribute" variable were statistically significant and positive for all income groups (columns 2-4). For Mexico (panel B), the coefficient for contribution was only significant for the middle income group, with coefficients that are much smaller in size for the lower and the higher income group. However, the results presented in column 5, for both countries, show that the interactions between the "contribute" variable and income groups are not statistically significant, suggesting that there is a similar valuation across all income groups.

In sum, our results for Peru reject both hypotheses. Regarding the first, that is, that participation in social security is low because workers do not value social security; we found that even after controlling for a host of personal and work-related variables, such as job security, hours of work, or occupational category that is correlated to formality, contributing to social security is associated with higher levels of job satisfaction. We interpret this finding as a signal that workers 
place positive value in social security. Regarding the second, that is, that participation is particularly low at the lower end of the skills and income distribution because lower-income, lower-skill workers value social insurance less than other workers, we did not find the evidence to be consistent with it either, as we did not find significant differences across income or education groups.

The results, however, point to a different situation in Mexico. Once we controlled for a large number of correlates of informality, we did not find evidence that contributing to social security is positively associated with job satisfaction. These low levels of significance are driven by both a lower number of observations and significantly lower coefficients, particularly for the low education group. This could suggest that the hypothesis of low valuation, particularly for low-skill workers, is an appropriate one for Mexico. These results also point to potential differences in the drivers of informality in both countries.

\section{Dealing with Endogeneity}

Given the potential problems of endogeneity, we present additional IV estimates using the instruments described in section 2. Results in tables 7 and 8 for Peru and Mexico, respectively, present instrumental variables estimates using a dummy dependent variable of job satisfaction. We split both tables into two panels, one for each instrument. We present the results of estimating linear probability models without interactions (columns 1 and 4) (equivalent to specification in column 7 in tables 3 and 4) and with education (columns 2 and 5) and income interactions (columns 3 and 6) estimated using the same number of observations as in the instrumental variables specifications. This allows comparing IV and OLS with the same number of observations, given that only 4,110 out of the 6,267 in Peru and 899 out of 2,371 in Mexico responded to the question regarding the number of friends enrolled in social security.

First-stage results showed that, as expected, the instruments were highly and positively correlated with contributing to social security. Additionally, both had a high F test (higher than 10), particularly the instrument "friends," which suggests that the first is a stronger instrument than the second but both are correlated with the instrumented variable.

For Peru, results were qualitatively similar with and without instrumental variables. The IV “friends” yielded higher coefficients and higher statistical significance for the variable "contribute." In all cases, the IV coefficient for "contribute” was positive and statistically significant, corroborating our previous results that individuals in Peru value access to social insurance. Quite remarkably, while the IV results suggest that there are no significant differences between education 
levels regarding social security valuation, the results point to some differences across income levels, with middle- and higher-income individuals valuing social insurance less than lower-income individuals. Results for the second instrument in Peru were very similar to those presented in panel A but with higher coefficients, which may be due to the fact that this is a weaker instrument.

For Mexico, the results were also qualitatively similar for IVs and linear probability models. In all cases but one (panel A, column 5), the variable "contribute” did not appear to affect job satisfaction. One exception is when the "contribute” variable interacted with education groups. In that case, the variable "contribute" — which now should be interpreted as the effect of "contribute" on job satisfaction for the low-skilled working population — was positive and statistically significant.

Table 9 shows the results of using each instrument separately and both instruments jointly (Peru in panel A and Mexico in panel B). All instruments yielded similar estimates in the case of Peru, while in the case of Mexico, using both IV models yielded a coefficient on social security that was positive and statistically significant.

The former results indicate that the relationship between social security contributions and job satisfaction is stronger in the IV estimation than in the OLS. In the case of Peru, this reinforces the positive relationship found between social security contributions and job security. In the case of Mexico, the IV results showed a few instances where the coefficient of the variable "contribute" was positive, but in general, the relationship was weak and statistically insignificant. Regarding interactions, using IV, we found little evidence than the poor or the low skilled value social insurance less. If anything, the valuation decreases with income and/or education attainment, and therefore, it is difficult to argue that lower-income or lower-skill individuals are less likely to be affiliated with social insurance because they do not value it.

\section{Discussion}

Our results suggest that, at least in the case of Peru, workers value social insurance, and therefore, the cause of low social insurance participation rates, particularly among low-income/lowskilled individuals, has to be found somewhere else. One possible explanation is that workers value these jobs, but given their productivity, market wages, and mandatory non-wage costs, they are not offered formal jobs, which would be in line with the exclusion hypothesis of informality. The high wage and particularly non-wage costs relative to workers' productivity observed in Peru may contribute to low job creation and exclude workers from formal jobs. Of course, it is also possible 
that even if Peruvian workers value social insurance, the package of wages and contributory and noncontributory benefits-adjusting by the costs of social insurance-remains more attractive in the informal sector.

In the case of Mexico, the evidence suggests that workers derive little additional satisfaction in having access to social insurance since, everything else equal; job satisfaction of formal workers is not statistically different to that of informal workers. This low added value of social insurance can be the result of an institutional environment where, on the one hand, the relationship contributions/benefits within social insurance are less favorable than in Peru, and, on the other hand, many informal workers get noncontributory social insurance benefits. Both aspects may conspire to make social insurance less attractive and reduce workers' willingness to pay for contributory social programs (see Levy 2008).

\section{Concluding Remarks}

In a context of high job informality in Latin America, this paper contributes to the literature by examining workers' preferences (valuation) for formal jobs. We find that, controlling for a wide set of individual and job characteristics, contributing to social insurance is associated with higher job satisfaction. In addition, the results also suggest that social insurance valuation does not increase with income or education attainment. If anything, such valuation decreases for more skilled/richer individuals.

Given these results, and in a context of rapid population aging, it is important to further investigate the causes behind the low participation in social security of low-skill workers. We found results that differ by country. For the case of Peru, we ruled out that low valuation is what drives low participation. What, then, drives informality? It may be that even if low-skill workers value social protection, they cannot afford it, being therefore driven to jobs that they value less. Similarly, it may be that low-income workers are not offered formal jobs because wage rigidities reduce the profitability of posting formal vacancies. Both explanations would be aligned with the exclusion hypothesis of informality. Things are different in Mexico, where workers do not place more value in jobs that provide social insurance, and therefore, they seem to choose to remain in the informal sector. This suggests that the causes of informality may differ across countries.

Another important hypothesis ruled out by our work is that the level of valuation for social insurance increases with income or skill levels. Therefore, it is not appropriate to state that the reason for lower participation rates among low-income, less educated people is driven by a lower 
appreciation of the benefits of social insurance. Our work indicates that borrowing constraints or exclusion from formal jobs, particularly in the case of Peru, may be a more reasonable hypothesis. 


\section{References}

Alaimo, Veronica, Mariano Bosch, David Kaplan, Carmen Pagés, and Laura Ripani. 2015. Empleos para Crecer. Washington, DC: Inter-American Development Bank.

Azuara, Oliver and Ioana Marinescu. 2013. "Informality and the expansion of social protection programs:Evidence from Mexico.” Journal of Health Economics, 32, 938- 950.

Bosch, Mariano, and William Maloney. 2007. "Gross Worker Flows in the Presence of Informal Labor Markets: Evidence from Mexico, 1987-2002.” IZA Discussion Paper 2864, IZA/Institute for the Study of Labor, Bonn, Germany.

Bosch, Mariano, Angel Melguizo and Carmen Pagés. 2013. Better Pensions Better Jobs, Washington, DC: Inter-American Development Bank.

David Card, Alexandre Mas, Enrico Moretti, and Emmanuel Saez. 2012. "Inequality at Work: The Effect of Peer Salaries on Job Satisfaction." American Economic Review, 102(6): 29813003.

Cornelissen, Thomas, John S. Heywood, and Uwe Jirjahn. 2011. "Performance Pay, Risk Attitudes and Job Satisfaction.” Labour Economics, 18 (2): 229-39.

Gao Wenshu and Russell Smyth. 2010. "Job Satisfaction and Relative Income in Economic Transition: Status or Signal? The Case of Urban China.” China Economic Review 21 (3): $442-55$.

Green, F. 2010. “Well-Being, Job Satisfaction and Labour Mobility.” Labour Economics 17:897903.

IDB (Inter-American Development Bank). 2004. Good Jobs Wanted: Labor Markets in Latin America. Economic and Social Progress in Latin America Report (IPES). Washington, DC: IDB.

IDB (Inter-American Development Bank). 2008. Understanding Quality of Life, Development in the Americas. Washington, DC: IDB.

IDB/OECD/WB (Inter-American Development Bank), Organization for Economic Cooperation and Development (OECD), and World Bank. 2015. Pensions at a Glance: Latin America and the Caribbean. Paris, France: IDB, OECD, and WB.

Jaramillo, Miguel. 2013. “Is There Demand for Formality among Informal Firms: Evidence from Microfirms in Downtown Lima.” Avances de investigación 13, Group for the Analysis of Development (GRADE). 
Levy, S. 2008. Good Intentions, Bad Outcomes: Social Policy, Informality and Economic Growth in Mexico. Washington, DC: Brookings Institution Press.

López Boo, Florencia, Lucia Madrigal and Carmen Pagés. 2010. "Part-Time Work, Gender and Job Satisfaction: Evidence from a Developing Country.” Journal of Development Studies, 46:9, 1543-1571.

Lusardi, Annamaria, and Olivia Mitchell. 2014. “The Economic Importance of Financial Literacy: Theory and Evidence.” Journal of Economic Literature 52:1, 5-44.

Maloney, William. 2004. “Informality Revisited.” World Development 32:1159-78.

Maloney, William. 1999. “Does Informality Imply Segmentation in Urban Labor Markets?

Evidence from Sectoral Transitions in Mexico.” World Bank Economic Review 13(2): 275302.

OECD (Organisation for Economic Co-operation and Development). 2014. Employment Outlook, Paris: OECD.

Pagés, Carmen and Lucia Madrigal. 2008. “Is Informality a Good Measure of Job Quality? Evidence from Job Satisfaction Data.” IDB Working Paper 654, Inter-American Development Bank Washington, DC.

Pagés, Carmen, and M. Stampini. 2007. "No Education, No Good Jobs? Evidence on the Relationship between Education and Labor Market Segmentation.” IZA Discussion Paper 3187, IZA/Institute for the Study of Labor, Bonn, Germany.

Perry, Guillermo, William Maloney, Omar Arias, Pablo Fajnzylber, Andrew Mason and Jaime Saavedra-Chanduvi. 2007. Informality: Exit and Exclusion. Washington, DC: World Bank. Rafael Rofman, Ignacio Apella, and Evelyn Vezza, Editors. 2014. Beyond Contributory Pensions: Fourteen Experiences with Coverage Expansion in Latin America. Washington, DC: World Bank.

van Rooij, Maarten , Annamaria Lusardi, and Rob Alessie. 2011. "Financial Literacy and Stock Market Participation.” Journal of Financial Economics 101:449-72. 


\section{Graphs and Tables}

Table 1. Information on the Countries under Study

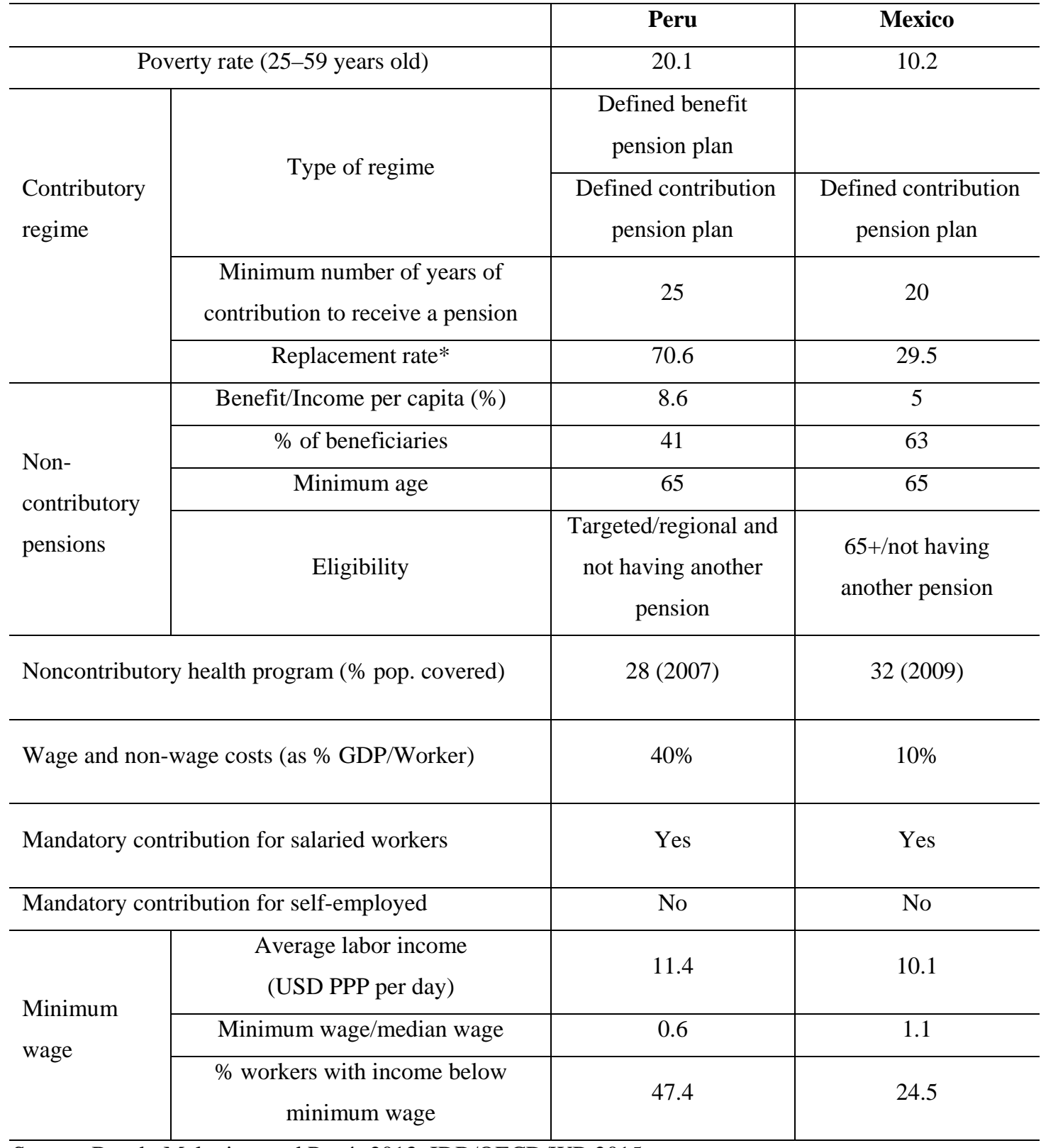

Source: Bosch, Melguizo, and Pagés 2013; IDB/OECD/WB 2015

Note: * Gross replacement rates relative to average wage. 
Graph 1: Percentage of Contributors to Social Insurance out of Total Employed by Income.

Latin America and the Caribbean. Workers 15-65 years old.

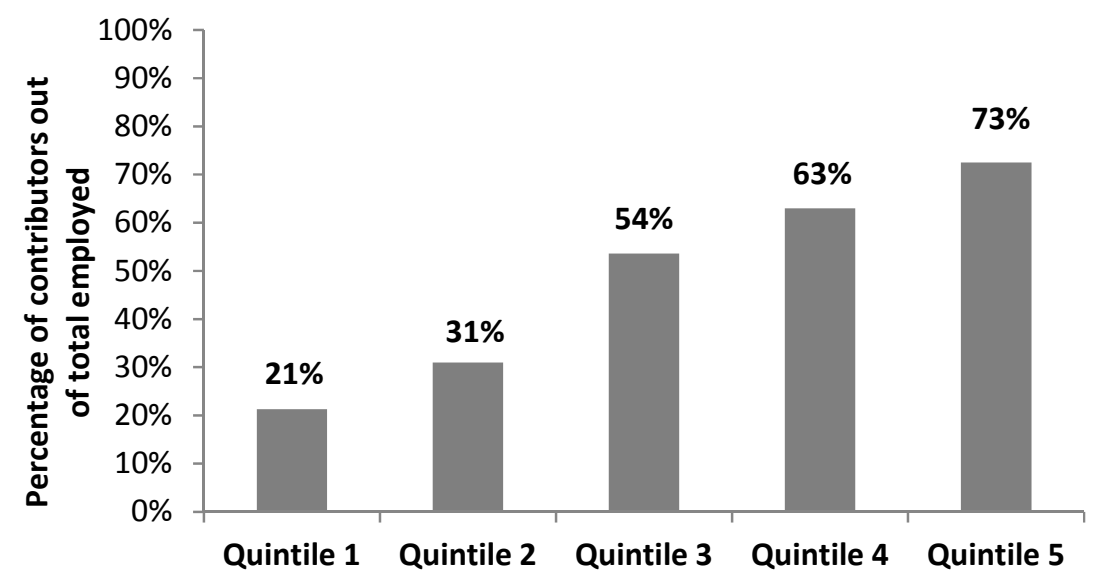

Source: Inter-American Development Bank out of household surveys of the region.

Note: Quintiles based on individual income.

Graph 2: Percentage of Contributors to Social Insurance out of Total Employed by Education.

Latin America and the Caribbean. Workers 15-65 years old.

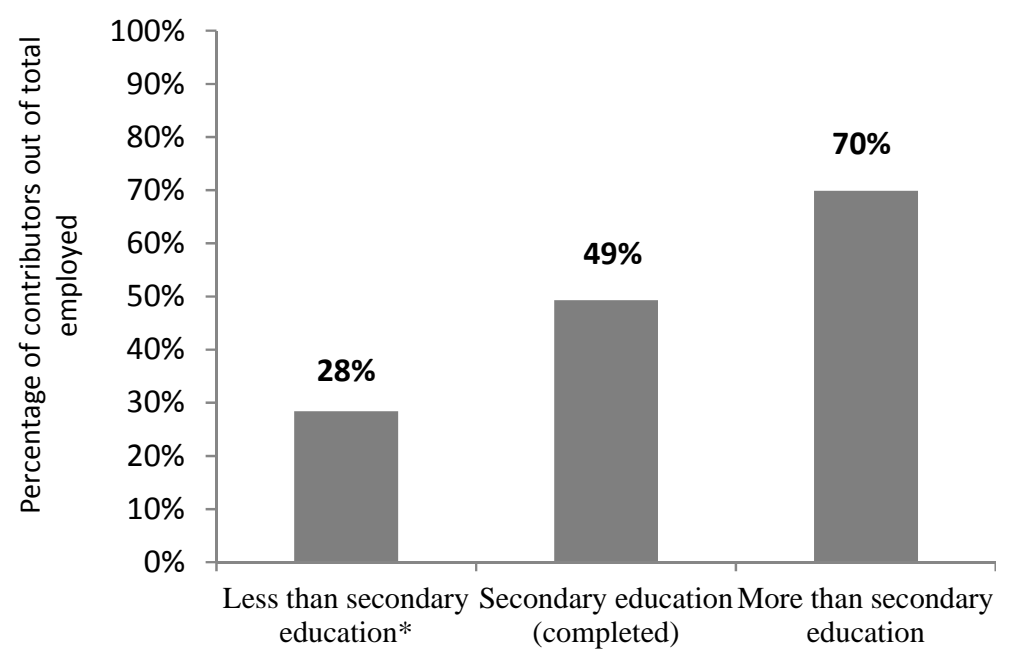

Source: Inter-American Development Bank out of household surveys of the region. 


\section{Graph 3. Job Satisfaction in Mexico and Peru}
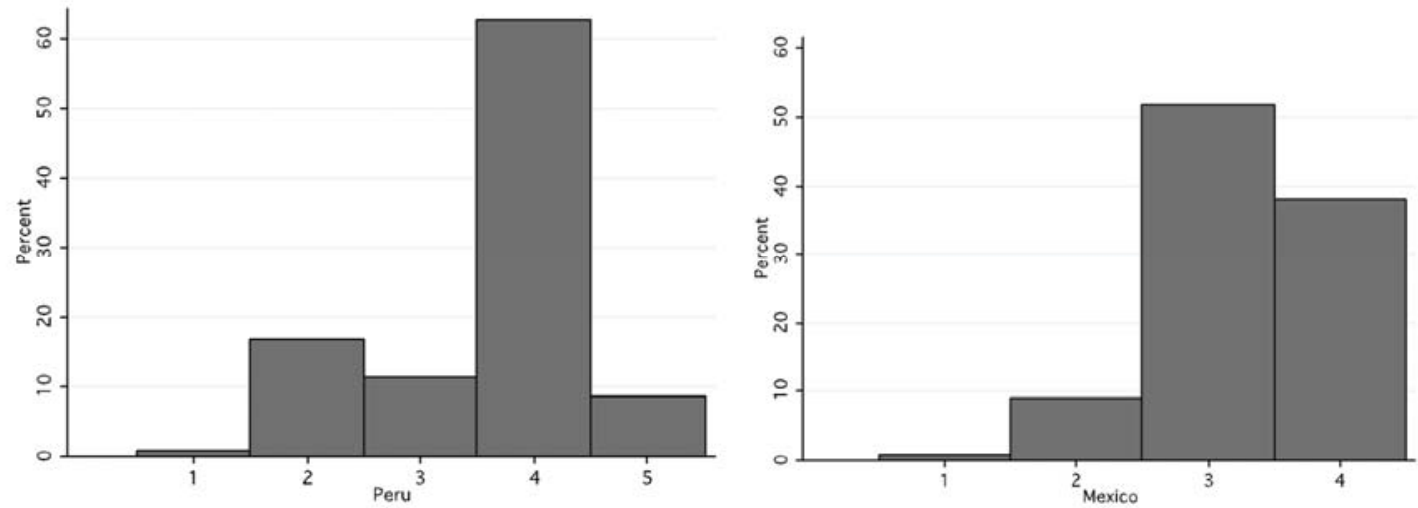

Note: In the " $x$ ” axis: In Peru, category 1 is “very unsatisfied,” 2 "unsatisfied,” 3 "indifferent,” 4 "satisfied,” and 5

“very satisfied.” In Mexico, category 1 is “very unsatisfied,” 2 “unsatisfied,” 3 “satisfied,” and 4 “very satisfied.” 
Table 2. Descriptive Statistics

Weighted sample of workers 25-55 years old

\begin{tabular}{|c|c|c|c|c|c|c|c|}
\hline & & \multicolumn{3}{|c|}{ Mexico } & \multicolumn{3}{|c|}{ Peru } \\
\hline & & Mean & SD & $\mathbf{N}$ & Mean & SD & $\mathbf{N}$ \\
\hline \multirow{6}{*}{ 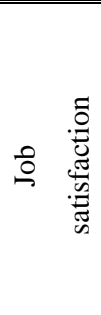 } & Very unsatisfied (VU) & 0.008 & $(0.089)$ & 3731 & 0.009 & $(0.094)$ & 6939 \\
\hline & Unsatisfied (U) & 0.082 & $(0.275)$ & 3731 & 0.183 & $(0.386)$ & 6939 \\
\hline & Indifferent (I) & --- & --- & --- & 0.131 & $(0.337)$ & 6939 \\
\hline & Satisfied (S) & 0.498 & $(0.500)$ & 3731 & 0.608 & $(0.488)$ & 6939 \\
\hline & Very satisfied (VS) & 0.411 & $(0.492)$ & 3731 & 0.070 & $(0.254)$ & 6939 \\
\hline & Job satisfaction dummy (1 = S or VS) & 0.910 & $(0.286)$ & 3731 & 0.678 & $(0.467)$ & 6939 \\
\hline \multirow{10}{*}{ 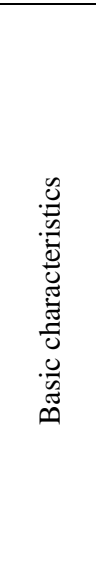 } & Contribute & 0.361 & $(0.480)$ & 3731 & 0.275 & $(0.447)$ & 6924 \\
\hline & Salaried & 0.707 & $(0.455)$ & 3731 & 0.551 & $(0.497)$ & 6939 \\
\hline & Male & 0.624 & $(0.484)$ & 3729 & 0.588 & $(0.492)$ & 6939 \\
\hline & Older ( $1=$ More than 40 years) & 0.404 & $(0.491)$ & 3731 & 0.378 & $(0.485)$ & 6939 \\
\hline & Married & 0.509 & $(0.500)$ & 3731 & 0.315 & $(0.465)$ & 6939 \\
\hline & Chronic health condition & 0.123 & $(0.329)$ & 3731 & 0.087 & $(0.282)$ & 6939 \\
\hline & Less than secondary completed & 0.264 & $(0.441)$ & 3729 & 0.231 & $(0.421)$ & 6939 \\
\hline & Secondary completed & 0.291 & $(0.454)$ & 3729 & 0.386 & $(0.487)$ & 6939 \\
\hline & Tertiary or university & 0.445 & $(0.497)$ & 3729 & 0.383 & $(0.486)$ & 6939 \\
\hline & $\begin{array}{c}\text { Education high } \\
(1=\text { Secondary completed or more })\end{array}$ & 0.736 & $(0.441)$ & 3729 & 0.769 & $(0.421)$ & 6939 \\
\hline \multirow{7}{*}{ 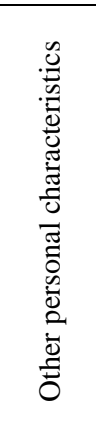 } & $\begin{array}{c}\text { Have thought some/much about } \\
\text { how to finance old age }\end{array}$ & 0.335 & $(0.472)$ & 3731 & 0.421 & $(0.494)$ & 6921 \\
\hline & Smoke & 0.316 & $(0.465)$ & 3728 & 0.132 & $(0.339)$ & 6938 \\
\hline & Plan with a lot of detail & 0.522 & $(0.500)$ & 3731 & 0.620 & $(0.485)$ & 6939 \\
\hline & Present oriented & 0.417 & $(0.493)$ & 3731 & 0.359 & $(0.480)$ & 6938 \\
\hline & Risk averse & 0.262 & $(0.440)$ & 3712 & 0.254 & $(0.435)$ & 6894 \\
\hline & Make time to check household budgets & 0.548 & $(0.498)$ & 3730 & 0.774 & $(0.418)$ & 6922 \\
\hline & Access to six months of income if needed & 0.374 & $(0.484)$ & 3714 & 0.378 & $(0.485)$ & 6924 \\
\hline \multirow{8}{*}{ 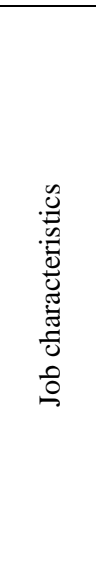 } & $\begin{array}{c}\text { Probability of being fired ( } 1=\text { not prob., } 2=\text { little } \\
\text { prob., } 3=\text { somewhat prob., } 4=\text { very prob.) }\end{array}$ & 1.5711 & $(0.732)$ & 3731 & 1.501 & $(0.659)$ & 6938 \\
\hline & Hours worked (by month) & 212.5 & $(65.351)$ & 3633 & 222.2 & (77.274) & 6655 \\
\hline & Manufacture & 0.102 & $(0.303)$ & 3722 & 0.157 & $(0.364)$ & 6896 \\
\hline & Large firm (1 = Firm of 10 people or more) & 0.451 & $(0.498)$ & 3731 & 0.339 & $(0.473)$ & 6939 \\
\hline & $\begin{array}{c}\text { Log of monthly income } \\
\text { (US dollars, PPP adjusted 2008) }\end{array}$ & 8.826 & $(0.736)$ & 2658 & 7.333 & $(0.560)$ & 6627 \\
\hline & Log of monthly income - Low income group & 8.047 & $(0.627)$ & 886 & 6.694 & $(0.275)$ & 1856 \\
\hline & Log of monthly income - Middle income ${ }^{(+)}$ & 8.783 & $(0.120)$ & 796 & 7.302 & $(0.157)$ & 2518 \\
\hline & Log of monthly income - Upper income ${ }^{(+)}$ & 9.488 & $(0.365)$ & 976 & 7.977 & $(0.312)$ & 2255 \\
\hline
\end{tabular}

Note: ${ }^{(+)}$Income categories are based on terciles of the income distribution. The values for income are shown in US dollars, PPP adjusted 2008. The numbers of observations in each category are not equal because there are many individuals in the sample who reported the same level of income. 
Table 3. Peru - Determinants of Job Satisfaction

Weighted sample of workers 25-55 years old

\begin{tabular}{|c|c|c|c|c|c|c|c|}
\hline & (1) & (2) & (3) & (4) & (5) & (6) & (7) \\
\hline & $\begin{array}{l}\text { O. Probit } \\
\text { (Job Sat) }\end{array}$ & $\begin{array}{l}\text { O. Probit } \\
\text { (Job Sat) }\end{array}$ & $\begin{array}{l}\text { O. Probit } \\
\text { (Job Sat) }\end{array}$ & $\begin{array}{l}\text { O. Probit } \\
\text { (Job Sat) }\end{array}$ & $\begin{array}{l}\text { O. Probit } \\
\text { (Job Sat) }\end{array}$ & $\begin{array}{l}\text { O. Probit } \\
\text { (Job Sat) }\end{array}$ & $\begin{array}{c}\text { (Job } \\
\text { satisfaction } \\
\text { dummy) }\end{array}$ \\
\hline Contribute & $\begin{array}{c}0.101^{* * *} \\
(0.010)\end{array}$ & $\begin{array}{c}0.102^{* * *} \\
(0.011)\end{array}$ & $\begin{array}{c}0.091^{* * *} \\
(0.012)\end{array}$ & $\begin{array}{c}0.088^{* * *} \\
(0.012)\end{array}$ & $\begin{array}{c}0.090 * * * \\
(0.012)\end{array}$ & $\begin{array}{c}0.073^{* * *} \\
(0.013)\end{array}$ & $\begin{array}{c}0.116^{* * *} \\
(0.024)\end{array}$ \\
\hline Salaried & & $\begin{array}{c}-0.062^{* * *} \\
(0.015)\end{array}$ & $\begin{array}{c}-0.060 * * * \\
(0.016)\end{array}$ & $\begin{array}{c}-0.040^{* *} \\
(0.017)\end{array}$ & $\begin{array}{c}-0.041^{* *} \\
(0.017)\end{array}$ & $\begin{array}{c}-0.036^{* *} \\
(0.016)\end{array}$ & $\begin{array}{c}-0.081^{* * *} \\
(0.026)\end{array}$ \\
\hline Large firm & & $0.035^{* * *}$ & $0.031 * *$ & $0.035^{* * *}$ & $0.036^{* *}$ & $0.026^{*}$ & $0.077 * * *$ \\
\hline $\begin{array}{c}(1=\text { Firm of } 10 \text { or } \\
\text { more })\end{array}$ & & $(0.012)$ & $(0.012)$ & $(0.013)$ & $(0.014)$ & $(0.015)$ & $(0.024)$ \\
\hline Male & & $\begin{array}{c}-0.017^{* *} \\
(0.008)\end{array}$ & $\begin{array}{l}-0.016^{* *} \\
(0.008)\end{array}$ & $\begin{array}{l}-0.016 * \\
(0.009)\end{array}$ & $\begin{array}{c}-0.025^{* *} \\
(0.010)\end{array}$ & $\begin{array}{c}-0.057^{* * * *} \\
(0.011)\end{array}$ & $\begin{array}{c}-0.088 * * * \\
(0.017)\end{array}$ \\
\hline Older & & $-0.023^{* *}$ & $-0.026^{* *}$ & $-0.030 * * *$ & $-0.029 * * *$ & $-0.034 * * *$ & $-0.035^{* *}$ \\
\hline ( $1=$ More than 40 & & & & & & & \\
\hline years) & & $(0.009)$ & $(0.010)$ & $(0.010)$ & $(0.011)$ & $(0.012)$ & $(0.016)$ \\
\hline Education high & & $0.050 * * *$ & $0.037 * * *$ & $0.038 * * *$ & $0.044 * * *$ & $0.030 * *$ & $0.060 * * *$ \\
\hline (1 = Secondary or & & & & & & & \\
\hline more) & & $(0.013)$ & $(0.013)$ & $(0.013)$ & $(0.014)$ & $(0.013)$ & $(0.017)$ \\
\hline Married & & $\begin{array}{c}0.036 * * * \\
(0.011)\end{array}$ & $\begin{array}{l}0.028 * * \\
(0.011)\end{array}$ & $\begin{array}{l}0.026 * * \\
(0.011)\end{array}$ & $\begin{array}{l}0.028 * * \\
(0.012)\end{array}$ & $\begin{array}{c}0.019 \\
(0.014)\end{array}$ & $\begin{array}{c}0.026 \\
(0.020)\end{array}$ \\
\hline Chronic health & & -0.010 & -0.010 & -0.009 & -0.011 & -0.013 & $-0.046^{*}$ \\
\hline condition & & $(0.019)$ & $(0.018)$ & $(0.018)$ & $(0.017)$ & $(0.020)$ & $(0.027)$ \\
\hline Thought how to finance & & & $0.030 * * *$ & $0.028 * * *$ & $0.024 * * *$ & $0.016^{*}$ & 0.009 \\
\hline old age & & & $(0.009)$ & $(0.009)$ & $(0.009)$ & $(0.009)$ & $(0.014)$ \\
\hline Smoke & & & $\begin{array}{c}0.008 \\
(0.009)\end{array}$ & $\begin{array}{c}0.006 \\
(0.009)\end{array}$ & $\begin{array}{c}0.000 \\
(0.010)\end{array}$ & $\begin{array}{c}0.000 \\
(0.011)\end{array}$ & $\begin{array}{l}-0.000 \\
(0.018)\end{array}$ \\
\hline Plan with a lot of detail & & & $\begin{array}{l}0.023 * \\
(0.013)\end{array}$ & $\begin{array}{c}0.019 \\
(0.012)\end{array}$ & $\begin{array}{c}0.020 \\
(0.013)\end{array}$ & $\begin{array}{c}0.028 * * \\
(0.013)\end{array}$ & $\begin{array}{c}0.022 \\
(0.020)\end{array}$ \\
\hline Present oriented & & & $\begin{array}{c}-0.042^{* * *} \\
(0.010)\end{array}$ & $\begin{array}{c}-0.046^{* * *} \\
(0.010)\end{array}$ & $\begin{array}{c}-0.046^{* * *} \\
(0.012)\end{array}$ & $\begin{array}{c}-0.048 * * * \\
(0.012)\end{array}$ & $\begin{array}{c}-0.065 * * * \\
(0.016)\end{array}$ \\
\hline Risk averse & & & $\begin{array}{l}-0.009 \\
(0.015)\end{array}$ & $\begin{array}{l}-0.011 \\
(0.016)\end{array}$ & $\begin{array}{l}-0.009 \\
(0.017)\end{array}$ & $\begin{array}{l}-0.003 \\
(0.020)\end{array}$ & $\begin{array}{c}0.001 \\
(0.029)\end{array}$ \\
\hline Make time to check & & & 0.017 & 0.017 & 0.015 & 0.014 & 0.014 \\
\hline household budget & & & $(0.014)$ & $(0.014)$ & $(0.014)$ & $(0.015)$ & $(0.018)$ \\
\hline Access to six months of & & & $0.066 * * *$ & $0.064 * * *$ & $0.063 * * *$ & $0.053 * * *$ & $0.091^{* * *}$ \\
\hline income & & & $(0.011)$ & $(0.011)$ & $(0.011)$ & $(0.012)$ & $(0.016)$ \\
\hline Probability of being & & & & $-0.065 * * *$ & $-0.065 * * *$ & $-0.067 * * *$ & $-0.086 * * *$ \\
\hline fired & & & & $(0.009)$ & $(0.009)$ & $(0.010)$ & $(0.018)$ \\
\hline Hours worked & & & & & $0.000 * *$ & 0.000 & 0.000 \\
\hline (by month) & & & & & $(0.000)$ & $(0.000)$ & $(0.000)$ \\
\hline
\end{tabular}




\begin{tabular}{|c|c|c|c|c|c|c|c|}
\hline Manufacture & & & & & $\begin{array}{l}-0.007 \\
(0.014)\end{array}$ & $\begin{array}{c}0.006 \\
(0.015)\end{array}$ & $\begin{array}{c}0.002 \\
(0.022)\end{array}$ \\
\hline Income monthly & & & & & & $0.106^{* * *}$ & $0.130 * * *$ \\
\hline (log, USD PPP 2008) & & & & & & $(0.011)$ & $(0.014)$ \\
\hline Constant & & & & & --- & & $-0.200 *$ \\
\hline & & & & --- & & & $(0.106)$ \\
\hline Observations & 6924 & 6924 & 6859 & 6858 & 6537 & 6267 & 6267 \\
\hline Pseudo $\mathrm{R}^{2} / / \mathrm{R}^{2}$ & 0.022 & 0.032 & 0.044 & 0.054 & 0.056 & 0.069 & 0.125 \\
\hline
\end{tabular}

Note: Models 1 to 6 are ordered Probit. Dependent variable is job satisfaction (from 1 - very unsatisfied to 5 - very satisfied). Marginal effects for the "very satisfied" option are shown in the table. Model 7 uses OLS. Dependent variable is job satisfaction (dummy, $1=$ satisfied/very satisfied). Robust standard errors in parentheses. $* p<$ $0.1 ; * * p<0.05 ; * * * p<0.01$ 
Table 4. Mexico - Determinants of Job Satisfaction

Weighted sample of workers 25-55 years old

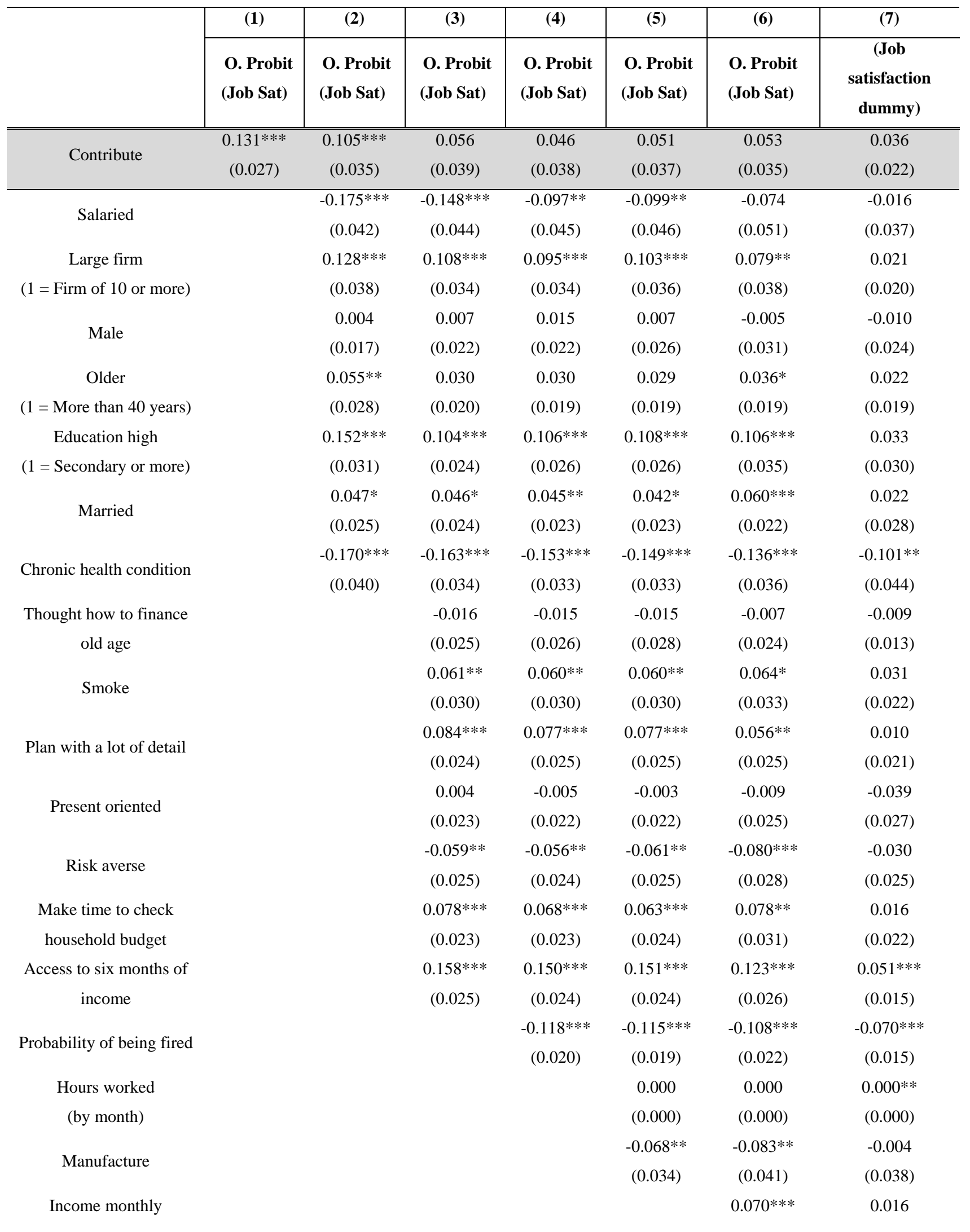


(log, USD PPP 2008)

$$
(0.020)
$$

(0.014)

\begin{tabular}{cccccccc} 
Constant & --- & -- & -- & -- & - & $0.751^{* * *}$ \\
& & & & & --- & $(0.119)$ \\
\hline Observations & 3731 & 3727 & 3307 & 3307 & 3208 & 2371 & 2371 \\
Pseudo $\mathrm{R}^{2} / / \mathrm{R}^{2}$ & 0.010 & 0.051 & 0.080 & 0.099 & 0.100 & 0.107 & 0.097 \\
\hline
\end{tabular}

Note: Models 1 to 6 are ordered probit. Dependent variable is job satisfaction (from 1 - very unsatisfied to 4 - very satisfied). Marginal effects for "very satisfied" option are shown in the table. Model 7 uses OLS. Dependent variable is job satisfaction (dummy, $1=$ satisfied/very satisfied). Robust standard errors in parentheses. $* p<0.1$; ** $p<0.05$; *** $\mathrm{p}<0.01$ 
Table 5. Testing Differences in SS Valuation, by Education

Panel A. Peru - Ordered probit with interactions

Weighted sample of workers $25-55$ years old

\begin{tabular}{|c|c|c|c|c|c|c|c|c|c|c|c|}
\hline & \\
\hline & \multirow{2}{*}{ (1) } & \multicolumn{4}{|c|}{ Education } & & \multirow{2}{*}{ (1) } & \multicolumn{4}{|c|}{ Education } \\
\hline & & (2) & (3) & (4) & (5) & & & (2) & (3) & (4) & (5) \\
\hline & $\begin{array}{c}\text { Base } \\
\text { model }^{(+)}\end{array}$ & $\begin{array}{l}\text { Less than } \\
\text { secondary } \\
\text { completed }\end{array}$ & $\begin{array}{l}\text { Secondary } \\
\text { completed }\end{array}$ & $\begin{array}{l}\text { Tertiary or } \\
\text { university }\end{array}$ & $\begin{array}{l}\text { Education } \\
\text { interaction }\end{array}$ & & $\begin{array}{c}\text { Base } \\
\text { model } \\
(+)\end{array}$ & $\begin{array}{l}\text { Less than } \\
\text { secondary } \\
\text { completed }\end{array}$ & $\begin{array}{l}\text { Secondary } \\
\text { completed }\end{array}$ & $\begin{array}{l}\text { Tertiary or } \\
\text { university }\end{array}$ & $\begin{array}{l}\text { Education } \\
\text { interaction }\end{array}$ \\
\hline Contribute & $\begin{array}{c}0.073^{* * *} \\
(0.013)\end{array}$ & $\begin{array}{c}0.082 \\
(0.055)\end{array}$ & $\begin{array}{c}0.108^{* * *} \\
(0.019)\end{array}$ & $\begin{array}{c}0.032^{* * *} \\
(0.011)\end{array}$ & $\begin{array}{c}0.049 \\
(0.040)\end{array}$ & Contribute & $\begin{array}{l}0.053 \\
(0.035)\end{array}$ & $\begin{array}{c}0.010 \\
(0.041)\end{array}$ & $\begin{array}{c}0.090 \\
(0.063)\end{array}$ & $\begin{array}{c}0.041 \\
(0.046)\end{array}$ & $\begin{array}{c}0.025 \\
(0.062)\end{array}$ \\
\hline $\begin{array}{l}\text { Secondary } \\
\text { completed } \\
\text { Tertiary or } \\
\text { university }\end{array}$ & & & & & $\begin{array}{c}0.013 \\
(0.013) \\
0.045^{* *} \\
(0.022)\end{array}$ & $\begin{array}{l}\text { Secondary } \\
\text { education } \\
\text { Tertiary or } \\
\text { university }\end{array}$ & & & & & $\begin{array}{c}0.095^{* *} \\
(0.043) \\
0.110^{* *} \\
(0.050)\end{array}$ \\
\hline $\begin{array}{c}\text { Secondary- } \\
\text { contribute } \\
\text { (Interaction) } \\
\text { Tertiary- } \\
\text { contribute } \\
\text { (Interaction) }\end{array}$ & & & & & $\begin{array}{c}0.043 \\
(0.029) \\
0.018 \\
\\
(0.041)\end{array}$ & $\begin{array}{c}\text { Secondary- } \\
\text { contribute } \\
\text { (Interaction) } \\
\text { Tertiary- } \\
\text { contribute } \\
\text { (Interaction) }\end{array}$ & & & & & $\begin{array}{c}-0.016 \\
(0.076) \\
0.066 \\
(0.060)\end{array}$ \\
\hline $\begin{array}{c}\text { Basic } \\
\text { characteristics }\end{array}$ & Yes & Yes & Yes & Yes & Yes & $\begin{array}{c}\text { Basic } \\
\text { characteristics }\end{array}$ & Yes & Yes & Yes & Yes & Yes \\
\hline $\begin{array}{l}\text { Other personal } \\
\text { characteristics }\end{array}$ & Yes & Yes & Yes & Yes & Yes & $\begin{array}{l}\text { Other personal } \\
\text { characteristics }\end{array}$ & Yes & Yes & Yes & Yes & Yes \\
\hline Job characteristics & Yes & Yes & Yes & Yes & Yes & Job characteristics & Yes & Yes & Yes & Yes & Yes \\
\hline Observations & 6267 & 1267 & 2388 & 2612 & 6267 & Observations & 2371 & 692 & 697 & 982 & 2371 \\
\hline Pseudo $\mathrm{R}^{2}$ & 0.069 & 0.053 & 0.055 & 0.068 & 0.070 & Pseudo R ${ }^{2}$ & 0.107 & 0.080 & 0.092 & 0.118 & 0.109 \\
\hline
\end{tabular}

Note: Ordered probit. Dependent variable is job satisfaction (all categories). Marginal effects for "very satisfied" option are shown in the table. Robust standard errors in parentheses. The income categories are based on terciles of the income distribution. Omitted categories: less than secondary education and lower income. Full specification available upon request. $(+)$ Base model $=$ tables 3 and 4, specification 6 . The numbers of observations in each category are not equal because there are many individuals in the sample who reported the same level of income. * $p<0.1$; $* * p<0.05$; $* * * p<$ 0.01

Panel B. Mexico - Ordered probit with interactions

Weighted sample of workers $25-55$ years old 
Table 6. Testing Differences in SS Valuation, by Income

Panel A. Peru - Ordered probit with interactions

Weighted sample of workers $25-55$ years old

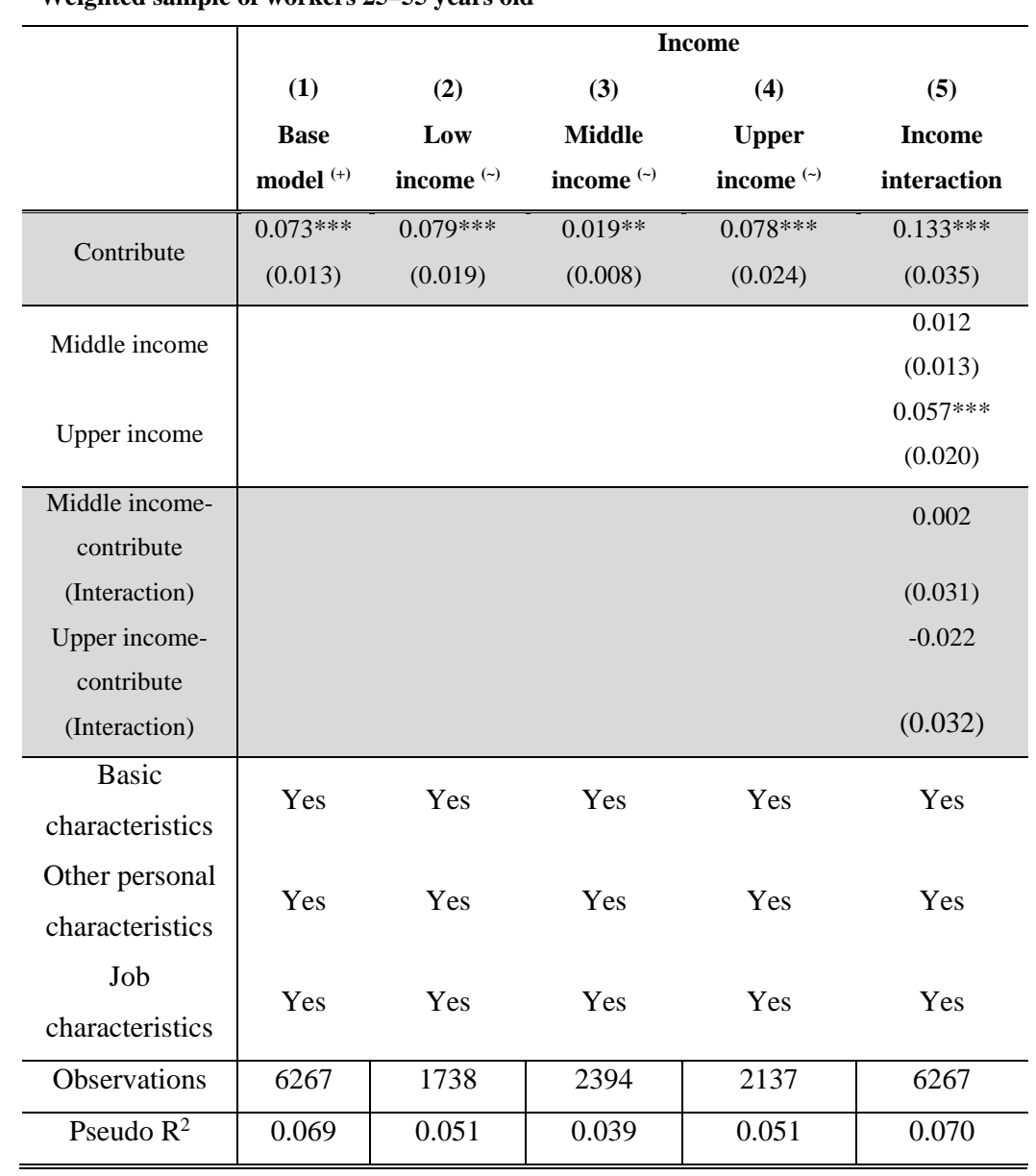

Panel B. Mexico - Ordered probit with interactions

Weighted sample of workers $25-55$ years old

\begin{tabular}{|c|c|c|c|c|c|}
\hline & \multicolumn{5}{|c|}{ Income } \\
\hline & $\begin{array}{c}\text { (1) } \\
\text { Base } \\
\text { model }^{(+)}\end{array}$ & $\begin{array}{c}\text { (2) } \\
\text { Low } \\
\text { income }^{(\sim)}\end{array}$ & $\begin{array}{c}\text { (3) } \\
\text { Middle } \\
\text { income }^{(\sim)}\end{array}$ & $\begin{array}{c}(4) \\
\text { Upper } \\
\text { income }^{(\sim)}\end{array}$ & $\begin{array}{c}\text { (5) } \\
\text { Income } \\
\text { interaction }\end{array}$ \\
\hline Contribute & $\begin{array}{c}0.053 \\
(0.035)\end{array}$ & $\begin{array}{c}0.051 \\
(0.061)\end{array}$ & $\begin{array}{c}0.119 * * * \\
(0.043)\end{array}$ & $\begin{array}{l}-0.010 \\
(0.061)\end{array}$ & $\begin{array}{c}0.067 \\
(0.083)\end{array}$ \\
\hline Middle income & & & & & $\begin{array}{c}0.036 \\
(0.040)\end{array}$ \\
\hline Upper income & & & & & $\begin{array}{c}0.187 * * * \\
(0.053)\end{array}$ \\
\hline $\begin{array}{l}\text { Middle income- } \\
\text { contribute } \\
\text { (Interaction) }\end{array}$ & & & & & $\begin{array}{l}0.004 \\
(0.095)\end{array}$ \\
\hline $\begin{array}{l}\text { Upper income- } \\
\text { contribute } \\
\text { (Interaction) }\end{array}$ & & & & & $\begin{array}{l}-0.044 \\
(0.107)\end{array}$ \\
\hline $\begin{array}{c}\text { Basic } \\
\text { characteristics }\end{array}$ & Yes & Yes & Yes & Yes & Yes \\
\hline $\begin{array}{l}\text { Other personal } \\
\text { characteristics }\end{array}$ & Yes & Yes & Yes & Yes & Yes \\
\hline $\begin{array}{c}\text { Job } \\
\text { characteristics }\end{array}$ & Yes & Yes & Yes & Yes & Yes \\
\hline Observations & 2371 & 785 & 703 & 883 & 2371 \\
\hline Pseudo $\mathrm{R}^{2}$ & 0.107 & 0.090 & 0.081 & 0.130 & 0.113 \\
\hline
\end{tabular}

Note: Ordered probit. Dependent variable is job satisfaction (all categories). Marginal effects for "very satisfied" option are shown in the table. Robust standard errors in parentheses. The income categories are based on terciles of the income distribution. Omitted categories: less than secondary education and lower income. Full specification available upon request.

$(+)$ Base model $=$ tables 3 and 4 , specification 6 . The numbers of observations in each category are not equal because there are many individuals in the sample who reported the same level of income. * $p<0.1 ; * * p<0.05 ; * * * p<0.01$ 
Table 7. Peru - Instrumental Variables

\begin{tabular}{|c|c|c|c|c|c|c|}
\hline \multicolumn{7}{|c|}{ Weighted sample of workers $25-55$ years old } \\
\hline & \multicolumn{6}{|c|}{ PANEL A - Instrument: Number of friends who contribute to pension system } \\
\hline & \multicolumn{3}{|c|}{ OLS results } & \multicolumn{3}{|c|}{$2^{\text {nd }}$ stage IV reg2 results } \\
\hline & (1) & (2) & (3) & (4) & (5) & (6) \\
\hline & No & Education & Income & No & Education & Income \\
\hline & interaction & interaction & interaction & interaction & interaction & interaction \\
\hline \multirow{2}{*}{ Contribute } & $0.133^{* * *}$ & 0.109 & $0.215^{* * *}$ & $0.223^{* * *}$ & $0.264^{* *}$ & $0.363^{* * *}$ \\
\hline & $(0.031)$ & $(0.091)$ & $(0.052)$ & $(0.061)$ & $(0.111)$ & $(0.114)$ \\
\hline Secondary-contribute & \multicolumn{3}{|c|}{0.091} & \multicolumn{3}{|c|}{-0.007} \\
\hline (Interaction) & \multicolumn{3}{|c|}{$(0.080)$} & \multicolumn{3}{|c|}{$(0.118)$} \\
\hline Tertiary-contribute & \multicolumn{3}{|c|}{-0.018} & \\
\hline (Interaction) & \multicolumn{3}{|c|}{$(0.092)$} & \multicolumn{3}{|c|}{$(0.101)$} \\
\hline Middle income- & \multirow{2}{*}{\multicolumn{3}{|c|}{$\begin{array}{l}-0.082 * \\
(0.048)\end{array}$}} & & \multirow{2}{*}{\multicolumn{2}{|c|}{$\begin{array}{l}-0.146^{*} \\
(0.083)\end{array}$}} \\
\hline contribute (Interaction) & & & & & & \\
\hline Upper income- & \multicolumn{3}{|r|}{$-0.117^{* * *}$} & & \multicolumn{2}{|r|}{$-0.215^{*}$} \\
\hline contribute (Interaction) & \multicolumn{3}{|r|}{$(0.042)$} & & \multicolumn{2}{|r|}{$(0.120)$} \\
\hline \multirow{2}{*}{$\begin{array}{c}\text { Basic characteristics } \\
\text { Other personal } \\
\text { characteristics }\end{array}$} & Yes & Yes & Yes & Yes & Yes & Yes \\
\hline & Yes & Yes & Yes & Yes & Yes & Yes \\
\hline Job characteristics & Yes & Yes & Yes & Yes & Yes & Yes \\
\hline \multirow{2}{*}{ Constant } & -0.037 & -0.029 & 0.159 & 0.069 & 0.028 & 0.259 \\
\hline & $(0.150)$ & $(0.148)$ & $(0.207)$ & $(0.144)$ & $(0.137)$ & $(0.200)$ \\
\hline Observations & 4110 & 4110 & 4110 & 4110 & 4110 & 4110 \\
\hline R-squared & 0.141 & 0.144 & 0.142 & 0.136 & 0.140 & 0.138 \\
\hline F 1st instrument & -- & -- & -- & 340.48 & 111.86 & 112.29 \\
\hline F 2nd instrument & -- & -- & -- & -- & 148.01 & 235.88 \\
\hline F 3rd instrument & -- & -- & -- & -- & 546.31 & 498.16 \\
\hline
\end{tabular}


Table 7. Peru - Instrumental Variables (Continuation)

\begin{tabular}{|c|c|c|c|c|c|c|}
\hline & \multicolumn{6}{|c|}{ PANEL B - Instrument: Familiarity with pension statement } \\
\hline & \multicolumn{3}{|c|}{ OLS results } & \multicolumn{3}{|c|}{$2^{\text {nd }}$ stage IV reg2 results } \\
\hline & $\begin{array}{c}(1) \\
\text { No } \\
\text { interaction }\end{array}$ & $\begin{array}{c}\text { (2) } \\
\text { Education } \\
\text { interaction }\end{array}$ & $\begin{array}{c}(3) \\
\text { Income } \\
\text { interaction }\end{array}$ & $\begin{array}{c}(4) \\
\text { No } \\
\text { interaction }\end{array}$ & $\begin{array}{c}\text { (5) } \\
\text { Education } \\
\text { interaction }\end{array}$ & $\begin{array}{c}\mathbf{( 6 )} \\
\text { Income } \\
\text { interaction }\end{array}$ \\
\hline Contribute & $\begin{array}{l}0.122 * * * \\
(0.024)\end{array}$ & $\begin{array}{c}0.099 \\
(0.086)\end{array}$ & $\begin{array}{l}0.200 * * * \\
(0.052)\end{array}$ & $\begin{array}{l}0.376^{* *} \\
(0.186)\end{array}$ & $\begin{array}{c}0.542 \\
(0.457)\end{array}$ & $\begin{array}{l}1.067 * * \\
(0.529)\end{array}$ \\
\hline $\begin{array}{l}\text { Secondary-contribute } \\
\text { (Interaction) }\end{array}$ & & $\begin{array}{c}0.078 \\
(0.071)\end{array}$ & & & $\begin{array}{l}-0.009 \\
(0.432)\end{array}$ & \\
\hline $\begin{array}{l}\text { Tertiary-contribute } \\
\text { (Interaction) }\end{array}$ & & $\begin{array}{l}-0.012 \\
(0.087)\end{array}$ & & & $\begin{array}{l}-0.322 \\
(0.388)\end{array}$ & \\
\hline $\begin{array}{c}\text { Middle income- } \\
\text { contribute (Interaction) }\end{array}$ & & & $\begin{array}{l}-0.058 \\
(0.048)\end{array}$ & & & $\begin{array}{l}-0.642 * \\
(0.383)\end{array}$ \\
\hline $\begin{array}{c}\text { Upper income- } \\
\text { contribute (Interaction) }\end{array}$ & & & $\begin{array}{c}-0.128 * * * \\
(0.046)\end{array}$ & & & $\begin{array}{l}-0.778^{*} \\
(0.424)\end{array}$ \\
\hline Basic characteristics & Yes & Yes & Yes & Yes & Yes & Yes \\
\hline $\begin{array}{l}\text { Other personal } \\
\text { characteristics }\end{array}$ & Yes & Yes & Yes & Yes & Yes & Yes \\
\hline Job characteristics & Yes & Yes & Yes & Yes & Yes & Yes \\
\hline Constant & $\begin{array}{l}-0.193^{*} \\
(0.106)\end{array}$ & $\begin{array}{l}-0.199^{*} \\
(0.108)\end{array}$ & $\begin{array}{c}0.154 \\
(0.146)\end{array}$ & $\begin{array}{c}0.098 \\
(0.268)\end{array}$ & $\begin{array}{l}-0.020 \\
(0.241)\end{array}$ & $\begin{array}{l}0.664^{* *} \\
(0.328)\end{array}$ \\
\hline Observations & 6191 & 6191 & 6191 & 6191 & 6191 & 6191 \\
\hline R-squared & 0.126 & 0.128 & 0.129 & 0.095 & 0.086 & 0.033 \\
\hline F 1st instrument & -- & - & -- & 29.55 & 11.05 & 19.62 \\
\hline F 2nd instrument & -- & -- & -- & -- & 35.97 & 35.05 \\
\hline F 3rd instrument & -- & -- & -- & -- & 45.78 & 90.25 \\
\hline
\end{tabular}

Note: Two instruments are presented: panel A - number of friends who contribute to the pension system (0-5) and panel B - familiarity with the pension statement. When using interactions, the instrument is constructed by multiplying the exogenous part of the interaction and the instrument (e.g., endogenous variable is "Secondary*Contribute," then the instrument is "Secondary*Friends"). For models without instruments (columns 1 to 3), the sample was adjusted to the one used for the instrumented specifications in order to facilitate comparison. Dependent variable is job satisfaction (dummy). OLS and IVreg2 results are shown. Omitted categories: less than secondary education and lower income category. Robust standard errors in parentheses. $* p<0.1 ; * * p<0.05 ; * * * p<0.01$ 
Table 8. Mexico - Instrumental Variables

Weighted sample of workers 25-55 years old

PANEL A - Instrument: Number of friends who contribute to the pension system OLS results $2^{\text {nd }}$ stage IV reg2 results

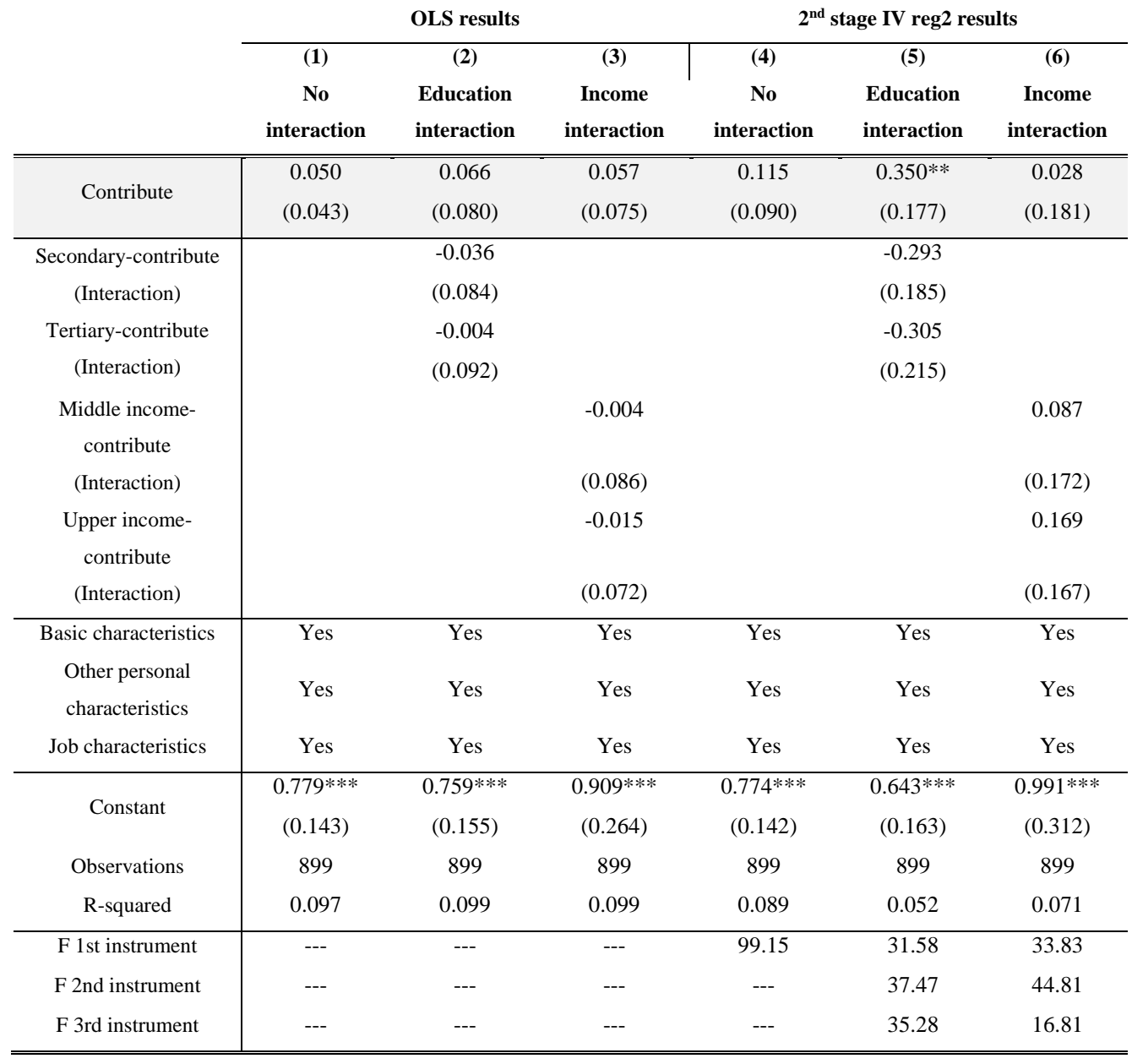


Table 8. Mexico - Instrumental Variables (Continuation)

\begin{tabular}{|c|c|c|c|c|c|c|}
\hline & \multicolumn{6}{|c|}{ PANEL B - Instrument: Familiarity with the pension statement } \\
\hline & \multicolumn{3}{|c|}{ OLS results } & \multicolumn{3}{|c|}{$2^{\text {nd }}$ stage IV reg2 results } \\
\hline & (1) & (2) & (3) & (4) & (5) & (6) \\
\hline & $\begin{array}{c}\text { No } \\
\text { interaction }\end{array}$ & $\begin{array}{l}\text { Education } \\
\text { interaction }\end{array}$ & $\begin{array}{c}\text { Income } \\
\text { interaction }\end{array}$ & $\begin{array}{c}\text { No } \\
\text { interaction }\end{array}$ & $\begin{array}{l}\text { Education } \\
\text { interaction }\end{array}$ & $\begin{array}{c}\text { Income } \\
\text { interaction }\end{array}$ \\
\hline Contribute & $\begin{array}{c}0.037 \\
(0.022)\end{array}$ & $\begin{array}{c}0.036 \\
(0.042)\end{array}$ & $\begin{array}{l}-0.000 \\
(0.049)\end{array}$ & $\begin{array}{c}0.237 \\
(0.203)\end{array}$ & $\begin{array}{c}0.353 \\
(0.389)\end{array}$ & $\begin{array}{c}0.392 \\
(0.353)\end{array}$ \\
\hline $\begin{array}{l}\text { Secondary- } \\
\text { contribute } \\
\text { (Interaction) }\end{array}$ & & $\begin{array}{l}-0.017 \\
(0.049)\end{array}$ & & & $\begin{array}{l}-0.111 \\
(0.313)\end{array}$ & \\
\hline $\begin{array}{c}\text { Tertiary-contribute } \\
\text { (Interaction) }\end{array}$ & & $\begin{array}{c}0.014 \\
(0.038)\end{array}$ & & & $\begin{array}{l}-0.168 \\
(0.320)\end{array}$ & \\
\hline $\begin{array}{c}\text { Middle income- } \\
\text { contribute } \\
\text { (Interaction) }\end{array}$ & & & $\begin{array}{c}0.066 \\
(0.080)\end{array}$ & & & $\begin{array}{l}-0.159 \\
(0.208)\end{array}$ \\
\hline $\begin{array}{c}\text { Upper income- } \\
\text { contribute } \\
\text { (Interaction) }\end{array}$ & & & $\begin{array}{c}0.038 \\
(0.073)\end{array}$ & & & $\begin{array}{l}-0.246 \\
(0.238)\end{array}$ \\
\hline Basic characteristics & Yes & Yes & Yes & Yes & Yes & Yes \\
\hline $\begin{array}{l}\text { Other personal } \\
\text { characteristics }\end{array}$ & Yes & Yes & Yes & Yes & Yes & Yes \\
\hline Job characteristics & Yes & Yes & Yes & Yes & Yes & Yes \\
\hline Constant & $\begin{array}{c}0.742 * * * \\
(0.118)\end{array}$ & $\begin{array}{c}0.739 * * * \\
(0.119)\end{array}$ & $\begin{array}{c}1.197 * * * \\
(0.245)\end{array}$ & $\begin{array}{c}0.768^{* * *} \\
(0.134)\end{array}$ & $\begin{array}{c}0.715^{* * *} \\
(0.121)\end{array}$ & $\begin{array}{c}1.139 * * * \\
(0.304)\end{array}$ \\
\hline Observations & 2315 & 2315 & 2315 & 2315 & 2315 & 2315 \\
\hline R-squared & 0.098 & 0.099 & 0.108 & 0.039 & 0.030 & 0.013 \\
\hline F 1st instrument & --- & --- & --- & 29.05 & 10.17 & 13.62 \\
\hline F 2nd instrument & --- & --- & --- & --- & 4.84 & 17.67 \\
\hline F 3rd instrument & -- & --- & -- & -- & 13.92 & 29.51 \\
\hline
\end{tabular}

Note: Two instruments are presented: panel A - number of friends who contribute to the pension system (0-5) and panel B - familiarity with the pension statement. When using interactions, the instrument is constructed by multiplying the exogenous part of the interaction and the instrument (e.g., endogenous variable is "Secondary*Contribute," then the instrument is "Secondary*Friends”). For models without instruments (columns 1 to 3 ), the sample was adjusted to the one used for the instrumented specifications in order to facilitate comparison. Dependent variable is job satisfaction (dummy). OLS and IVreg2 results are shown. Omitted categories: less than secondary education and lower income category. Robust standard errors in parentheses. ${ }^{*} p<0.1 ; * * p<0.05 ;{ }^{* * *} p<0.01$ 
Table 9. Instrumental Variables, Robustness Checks

\section{Panel A. Peru}

Weighted sample of workers $25-55$ years old

\begin{tabular}{c|c|c|c|}
\hline \multirow{3}{*}{ Instruments } & Dependent variable: Job satisfaction all categories & \multicolumn{2}{|c|}{ Dependent variable: Job satisfaction dummy } \\
\cline { 2 - 4 } & $\mathbf{( 1 )}$ & $\mathbf{( 2 )}$ & $\mathbf{( 3 )}$ \\
\cline { 2 - 4 } & $\begin{array}{c}\text { Ordered probit - } \\
\text { No instruments }\end{array}$ & No instruments & IV \\
\hline \hline "Friends" & $0.070^{* * *}$ & $0.133^{* * *}$ & $(0.061)$ \\
& $(0.016)$ & $(0.031)$ & $0.376^{* *}$ \\
"Familiarity with pension & & $0.122^{* * *}$ & $(0.186)$ \\
statement" & $0.077^{* * *}$ & $(0.024)$ & $0.235^{* * *}$ \\
"Friends" + "Familiarity & $(0.013)$ & & $(0.062)^{+}$ \\
with pension & & $0.134^{* * *}$ & $(0.030)$ \\
statement" & $0.071^{* * *}$ & & \\
\hline
\end{tabular}

Panel B. Mexico

Weighted sample of workers 25-55 years old

\begin{tabular}{|c|c|c|c|}
\hline \multirow{3}{*}{ Instruments } & \multirow{2}{*}{$\begin{array}{c}\text { Dependent variable: Job satisfaction all categories } \\
\text { (1) }\end{array}$} & \multicolumn{2}{|c|}{ Dependent variable: Job satisfaction dummy } \\
\hline & & (2) & (3) \\
\hline & $\begin{array}{l}\text { Ordered probit - } \\
\text { No instruments }\end{array}$ & $\begin{array}{c}\text { OLS - } \\
\text { No instruments }\end{array}$ & IV \\
\hline "Friends" & $\begin{array}{l}-0.009 \\
(0.074)\end{array}$ & $\begin{array}{c}0.050 \\
(0.043)\end{array}$ & $\begin{array}{c}0.115 \\
(0.090)\end{array}$ \\
\hline $\begin{array}{l}\text { "Familiarity with pension } \\
\text { statement" }\end{array}$ & $\begin{array}{c}0.055 \\
(0.035)\end{array}$ & $\begin{array}{c}0.037 \\
(0.022)\end{array}$ & $\begin{array}{c}0.237 \\
(0.203)\end{array}$ \\
\hline $\begin{array}{c}\text { "Friends" + "Familiarity } \\
\text { with pension } \\
\text { statement" }\end{array}$ & $\begin{array}{l}-0.005 \\
(0.072)\end{array}$ & $\begin{array}{c}0.047 \\
(0.042)\end{array}$ & $\begin{array}{l}0.158^{* *} \\
(0.076)^{+}\end{array}$ \\
\hline
\end{tabular}

Note: First column shows results for ordered probit model without instruments. Column 2 shows OLS results, and column 3 IVReg2. For these models, the dependent variable is job satisfaction (dummy). For models without instruments (specifications 1 and 3), the sample was adjusted to the one used for the instrumented specifications in order to facilitate comparison. Robust standard errors are in parentheses. IV results were obtained using the ivreg2 command in Stata.

+ The Hansen J statistic for the overidentification test for Peru is 1.665 (p-value 0.196) and for Mexico is 0.520 (p-value 0.471).

$* p<0.1 ; * *<0.05 ; * * * p<0.01$ 